\title{
MORPHOLOGICAL CLASSIFICATION OF BONE BIOPTIC SAMPLES WITH A POSSIBLE DETERMINATION OF SKELETON AGE IN CATTLE
}

\author{
H. ČRNÝ \\ Department of Morphology, University of Veterinary Science, 61242 Brno \\ Received February 13, 1979
}

\begin{abstract}
Černý, H.: Morphological Classification of Bone Bioptic Samples with a Possible Determination of Skeleton Age in Cattle. Acta vet. Brno, 49, 1980: 3-9.

The interrelationship was studied between the apophyseal cartilage and spongious bone on longitudinal macrosections of the tuber coxae and ala ossis ilium of 36 animals of one to 9 years of age, and on tissue section $4-7 \mu \mathrm{m}$ thick stained with hematoxylin and eosin of 240 bioptic samples from the tuber coxae of animals from 8 months to 9 years of age. On the basis of morphogenetical findings of the macro and microstructure the possibility was studied of determining the skeleton age.

In the 1st and 2 nd years the tuber coxae is completely formed by the apophyseal cartilage. The individual apophyseal ossification points form the spongious bone which substitutes the upper part of the cartilage. Thus, the remaining cartilage becomes the growth cartilage on the both ends of which ossification occurs. The continuous enchondral zone forms the ala ossis ilium at the distal end of the trabecula, the proximal end of the tuber coxae. The cartilage disappears at the age of 5-6 years. Results were compared with findings of the microstructure in histological sections; on the basis of these findings the classification was performed of bone bioptic samples corresponding in structure with the individual age categories.
\end{abstract}

Apophyseal cartilage, bone, age.

One of the most important methods of proving the changes of the morphological structure of the bone tissue with disorders of mineral metabolism is the histological and histochemical examination of intravitally obtained bone tissue. Besides a diagnostics of generalized changes of the structure the preparations from the bone cylinders provide valuable material for the determination of the skeleton age. According to the relationship between the cartilage and the bone tissue it is possible to determine the age up to 5-6 years. Considerable attention has been paid to the morphology of the cattle skeleton in Czechoslovak as well as in foreign literature.

In his monograph Kolda (1936) presented an extensive survey on the structure of the cattle skeleton as compared with other species of farm animals. He described the bone mainly from the point of view of its mechanical and supporting function. In other textbooks on veterinary anatomy we can find a similar approach and description of the skeleton and the individual bones of cattle as passive, supporting components of the locomotor apparatus.

Lind say (1969) dealt with the development of the individual bones of the appendicular bovine skeleton during ontogenesis with regard to the origin and existence of ossification centres in the prenatal and neonatal periods. In another work Lindsay (1969) described the ossification of the sternum in the same developmental stages as in the case of the appendicular skeleton.

Krahmer (1972) described postnatal growth changes of the bovine skeleton in the period from birth till the stage of finished growth which exceeded 5 years of age, with special regard to bones of the extremities.

Data on growth changes of the bovine skeleton from the prenatal and postnatal stages are de- 
pendent on findings of the gradual origin of the individual bones or on the determination of metric data expressing the dynamics of the skeleton development predominantly in the postnatal stage of development.

Wassilev's (1968) study is a classical osteometric one, dealing with osteometry of the pelvic bones with regard to changes in the different age categories.

Of greatest importance for the intravital sampling of bone tissue in cattle is the tuber coxae which, through its structural arrangement, is the most suitable place for osteobiopsy. Anatomical data concerning the growth and development of the tuber coxae are described together with the pelvic bones. However, the tuber coxae ossifies from independent apophyseal centres, as a cartilage it becomes attached with the ala ossis ilium and, in cattle, complete concrescence occurs at 5 years of age (Carlens, quot. Kolda 1936).

In the literature accessible there are no data on the dynamics of ossification with regard to the age of the animal. Such findings are very important for evaluation of bone bioptic samples, for the classification of the individual structures, and for determinations of the approximate age of the animals investigated, especially in those cases where we have no detailed anamnestic data.

\section{Materials and Methods}

Macroscopical proportions of the cartilage and spongious bone of the tuber coxae and ala ossis ilium were studied on longitudinal macrosections of 36 animals of the age from one to 9 years. Intravital sampling of the bone tissue from the tuber coxae using the modified method according to Bartelheimer was performed in 240 animals ranging from 8 months to 9 years of age. Tissue sections of a thickness of $4-7 \mu \mathrm{m}$ stained with hematoxylin and eosin were elaborated from bone cylinders $(6 \times 20-40 \mathrm{~mm})$.

On the basis of the relationship between the bone bioptic samples classification was performed determining the skeleton age.

\section{Results}

The tuber coxae in adult cattle is a $90-110 \mathrm{~mm}$ long and $35-45 \mathrm{~mm}$ wide ridge-like formation laterally protruding from the ala of the tuber coxae. It is divided into a cranial and caudal parts which are connected by the middle angle of the protuberance. The tuber coxae is the widest in the place of the middle angle. Morphogenesis of the tuber coxae:

At the time of birth the tuber coxae is formed by a cartilage only, later it is connected with an apophyseal cartilage as much as $20 \mathrm{~mm}$ thick. With advancing age of the animal the superficial cartilage weakens. The distal side of the cartilage forms a margin between the cartilage and spongiosa of the ala ossis ilium which originates through enchondral ossification from the superficial cartilage. The proximal side of the superficial cartilage is concave, covered with the perichondrium into which a layer of ligament is pressed.

In the first and second years the superficial cartilage covers the tuber coxae completely in such a way that it is the thickest at the cranio-dorsal and caudo-ventral part of the tuber. In the middle part, in the region of the middle angle of the tuber coxae, it is depressed in a concave way and is the thinnest in this part. On the surface it is covered with the perichondrium and the distal margin between the cartilage and spongiosa of the ala ossis ilium is formed by a new spongiosa originating from enchondral ossification of the apophyseal cartilage.

Towards the end of the second year, in some cases even earlier, separate apophyseal ossification centres begin to appear from which ossification occurs of the superficial apophyseal cartilage of the tuber coxae. The formed spongiosa forms a continuous strip separating the original superficial layer form the distal side. Due to this process the cartilage is supressed between the spongious trabeculae of the ala ossis ilium and the tuber coxae proper. In some cases the so oriented cartilage remains joined with the aid of cartilaginous trabeculae with the superficial layer.

At the age of 3-4 years the cartilage is found in the whole range between the 

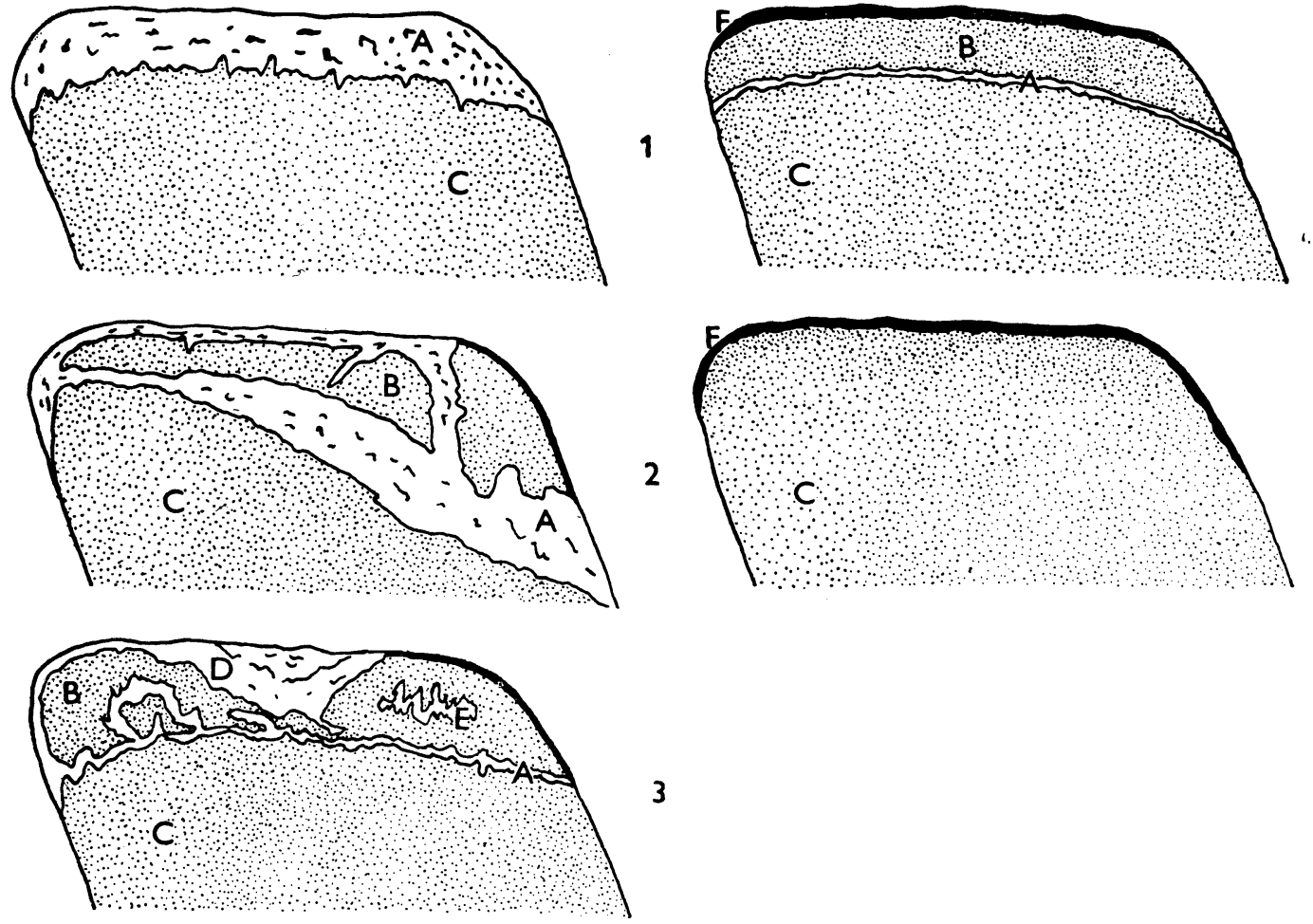

Fig. 1. Scheme of morphogenesis of tuber coxae showing the relationship of the cartilaginous and osseous tissue in different age categories of animals.

A - cartilage, B - trabeculae of the spongiosa of tuber coxae, C - spongious bone of ala ossis ilii, D - cartilage of middle angle of tuber, $\mathrm{E}$ - cartilaginous islet, F - periost.

$1-$ up to 2 years
$2-2$ to 3 years
$3-3$ to 4 years

$4-4$ to 5 years

5 - more than 5 years

spongiosa of the tuber coxae and the ala ossis ilium. In the place of the middle angle of the tuber coxae small patches and sometimes the remains of the originally entire superficial cartilage are yet found. The cartilage separating both spongious systems has the character of an epiphysodiaphyseal cartilage. The cartilage is only a few milimetres thick, on the macroscopical sections of the tuter coxae $3-4 \mathrm{~mm}$. The course of the cartilage is wavy and its projections lead into both the spongiosa of the tuber coxae and the trabeculae of the ala ossis ilium spongiosa. Remains of the superficial cartilage can be observed only in the region of the middle angle of the tuber coxae and they form a concave area on the surface. Small patches of the cartilage can also be found in the caudoventral part and, to a smaller extent, in the cranioventral part. In some cases we can observe minute cartilaginous patches irregularly depressed in the spongiosa of the tuber coxae which can communicate together through the cartilaginous trabeculae. The originated spongiosa of the tuber coxae changes into a compact enveloping layer on its surface with a periosteum which originated due to a differentiation of the original perichondrium. The outlasting cartilage is covered with perichondrium. 
In cattle of the age of 4-5 years we can observe a very thin cartilage, $2 \mathrm{~mm}$ thick, separating the spongiosa of the tuber and the ala ossium ilium. Only sporadically are cartilaginous patches found in the spongiosa of the tuber coxae where they gradually lose their continuity with the epiphyseal cartilage. The perichondrium differentiates into periosteum, so that in this age category a periosteum can be found already covering the whole surface of the tuber coxae.

Within the range of 5-6 years of age the growth cartilage in cattle disappears and thus both spongious parts are united into one whole. The trabeculae of the spongiosa of the tuber coxae change into spongious trabeculae of the ala ossis ilium. Characteristic for this age category is the fact that the tuber coxae completely grows together with the pelvic bones. The surface of the tuber coxae is covered with periosteum which changes into the periosteum of the ala ossis ilium.

\section{Classification of bioptic samples:}

Knowledge of macroscopical anatomical proportions concerning the relationships between the apophyseal cartilage, spongiosa and surface layer of the compact enable to classify the individual animals into age categories and it is a very valuable aid when classifying the bioptic samples of the bone tissue from the individual age categories.

Bioptic samples of the bone tissue have the shape of a cylinder $6 \mathrm{~mm}$ wide and $20-40 \mathrm{~mm}$ long. On the surface they are covered with a thin layer of collagenous ligament, fat ligament and, in some cases, with muscle tissue.

Bioptic samples from younger animals are covered with a superficial, apophyseal cartilage on the surface. With advancing age, separate apophyseal ossification centres appear in the cartilaginous tissue from which the cartilage gradually ossifies.

In some cases the advancing process of ossification separates the superficial part of the cartilage from the thick one. Ossification of the superficial part occurs separately, this part changes into the spongiosa of the tuber coxae. The perichondrium differentiates into the periosteum which forms the layer of the periosteal bone which transforms into a compact bone. In such a way the cartilage gets between the spongiosa of the tuber coxae and the spongious trabeculae of the ala ossis ilium. The cartilage is preserved up to the age of 5-6 years.

With advancing age the growth of the cartilage retards and its thickness continuously decreases. After being enclosed between the spongious trabeculae the cartilage is considerably thick in the first stage; at the same time changes taking place in the cartilaginous tissue can be observed. It is the formation of minute separate ossification centres from which the cartilage grad lally ossifies. In the next stage the ossification centres are united into larger entities and at the proximal margin they transform into spongious trabeculae of the tuber coxae. This process simultaneously weakens the cartilage. On the distal margin, on the continuous ossification zone formed, a new bone tissue is continuously forming through enchondral ossification.

As soon as the cartilage is of a particular thickness, the ossification activity disappears in the middle part of the cartilage and ossification occurs only on the cartilaginous sides, at the place of contact with the spongious bone. Ossification thus shifts to the periphery of the cartilage, to the margin between the cartilage and bone.

In the group of bioptic samples from animals older than 5-6 years, the cartilage was found between the two spongious systems. In these cases complete ossi- 
fication of the cartilage occurred. Sometimes, however, we can observe minute patches of cartilage, the presence of which indicates the earlier course of the growth cartilage. Bioptic samples of older cows have completely ossified cartilages, they are formed on the surface with an enveloping cortical bone compact covered with a periosteum.

The figures give the changes of all parts of the morphological structure of bone bioptic samples from the tuber coxae of cattle according to which we can simultaneously determine the skeleton age of the animals. The set of macrophotographs presents the most frequently occurring types of bone bioptic samples. In the figures we can follow the dynamic development of changes with regard to ageing and formations typical for the individual age categories.

The cortical layer is characteristic in that the bone lamellae form haversian systems around the vessels. These systems run in the direction of the vessels, i. e. parallelly with the surface of the tuber coxae. On the longitudinal section of the bone tissue cylinder the haversian systems are illustrated in a transverse plane.

As compared with the trabeculae of the spongiosa of the pelvic bones originating on the enchondral zone of the distal side of the growth cartilage, the spongious bone tissue of the tuber coxae proper can be characterized as a more compact trabeculae system in which the individual trabeculae are anastomotically connected with relatively thick intertrabecular connections.

\section{Discussion}

Despite the fact that there are many data in literature describing the origin and development of bones or skeleton as a whole, we lack a dynamic comparison of the development of bones with regard to age in the period of postnatal development. The dynamic development of bones in this period of development is given mostly in metric data through the gradual change of which is the dynamic process of the development and growth of bones expressed (Krahmer 1972; Wassilev 1968).

From the viewpoint of the requirements of present practice the tuber coxae has become an exposed locality for intravital sampling of the bone tissue. Carlens (qu. Kolda 1936) dealt with the development of the tuber coxae as an independent structure ossifying from its own apophyseal ossification centres. He proved that the coalescence of the separately developing tuber with the pelvic bones occurs at the age of 5 years. When investigating the morphogenesis of the tuber coxae the author of the present study observed that even in some cases in 5-year-old cattle the existence of the growth cartilage can be proved, which had, however lost its proliferating ability. It is therefore necessary to shift the term of total coalescence to the period of 5-6 years of age. The author cannot compare knowledge acquired on the morphogenesis of the tuber coxae in the younger age categories because accessible literature does not provide data on the dynamics of ossification.

Not only the convenient anatomical conditions make the tuber coxae a suitable locality for intravital sampling of the bone tissue for further investigations of the microstructure but also the relatively long period of the activity of the growth cartilage is very conve zient for recording the dynamics of the changes. Sampling of the bone tissue has been described many times in literature, incl. the methods of structural diagnostics, however, the relationship between the structures of apophyseal cartilage and the trabeculae of the spongious bone for the determination of the skeleton age have not been elaborated. 

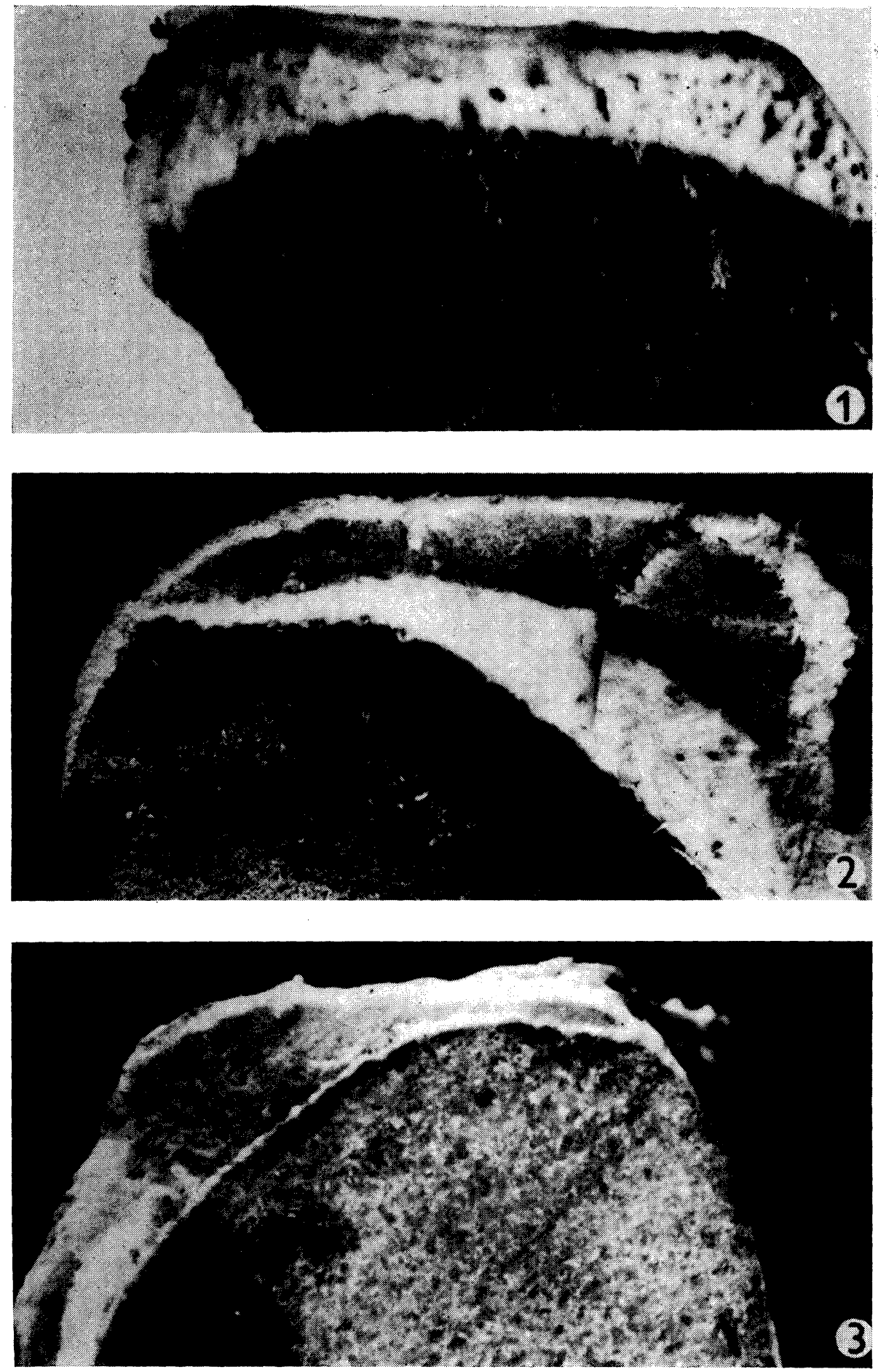


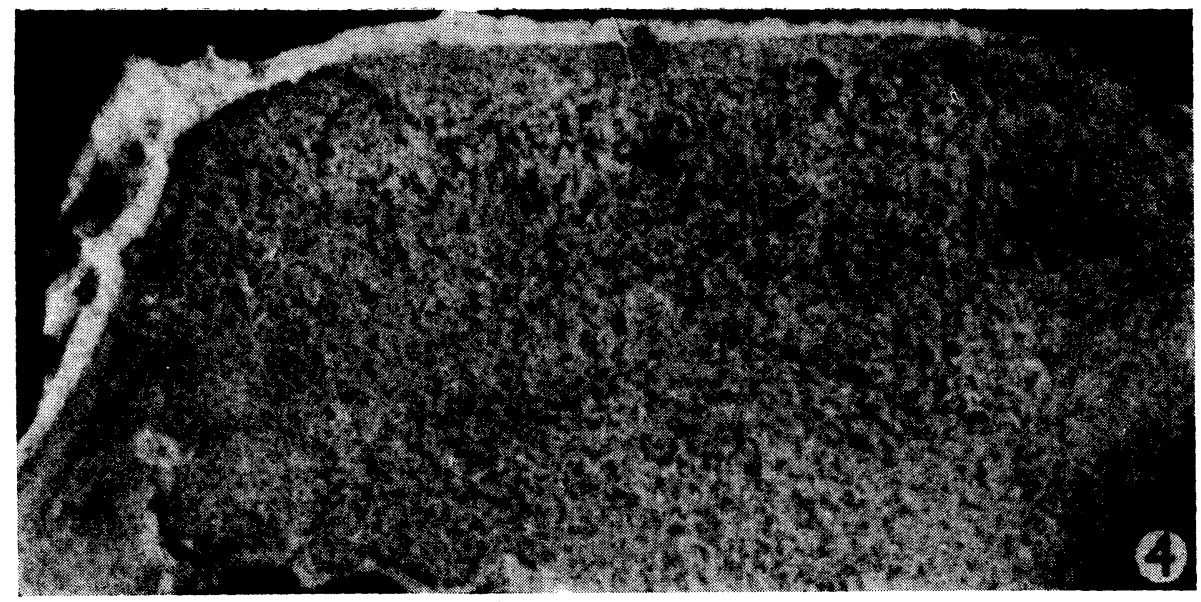

Fig. 2. Macroscopic longitudinal section through tuber coxae.

1 - apophyseal cartilage forming the tuber coxae (age 18 months)

2 - origin of the spongious bone of the tuber coxae proper and differentiation of the apophyseal cartilage into the superficial layer and growth cartilage (age 2-3 years)

3 - formed growth cartilage separating the spongious bone of tuber coxae from ala ossis ilii. Between the trabeculae of spongiosa of tuber coxae small islets of cartilage are visible (age $3-4$ years)

4 - section through the tuber coxae of an adult individual after ossification of the growth cartilage. The spongious bone of the tuber coxae fused with the ala ossis ilii, the surface of tuber coxae is covered with periost (age 9 years) 


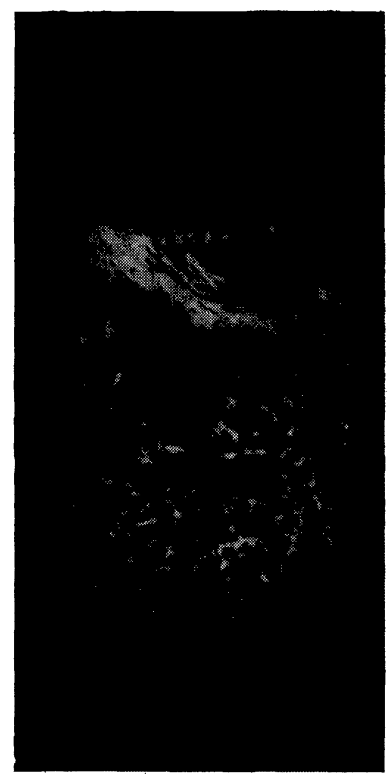

1

4

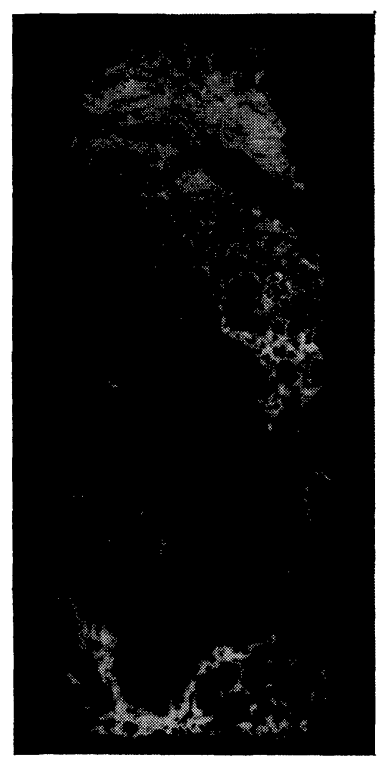

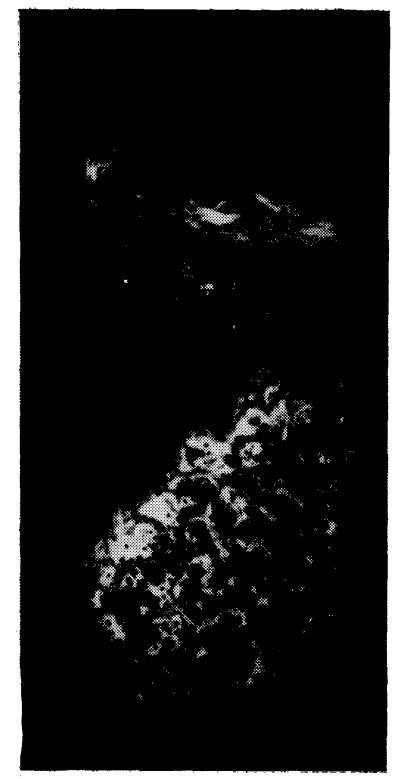

2

5

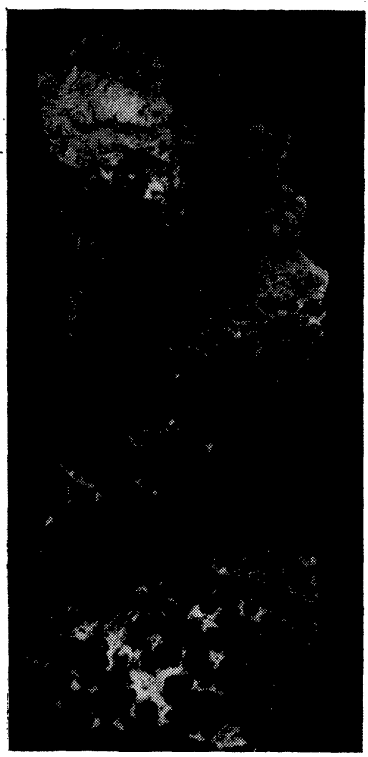

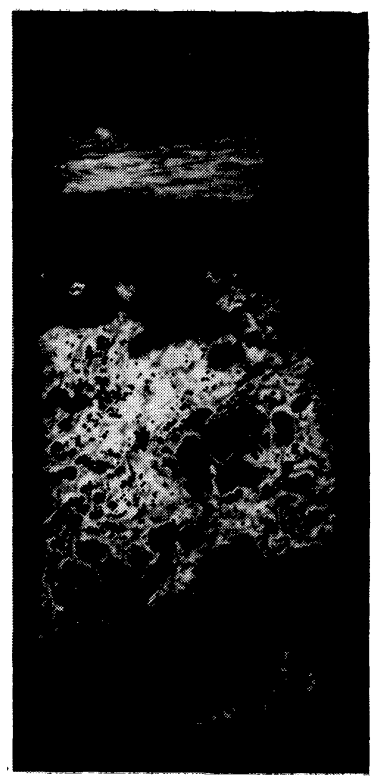

3

6

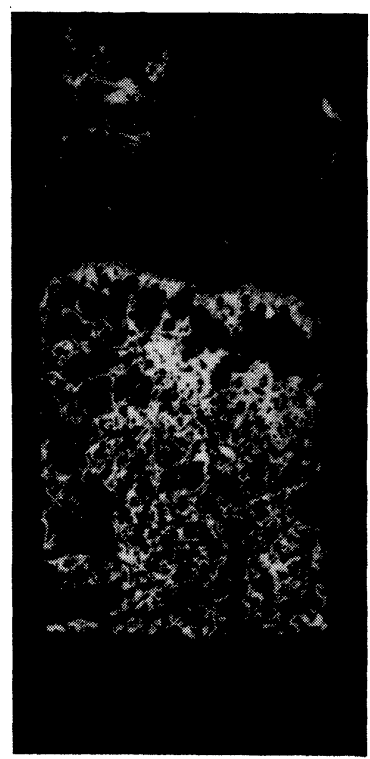




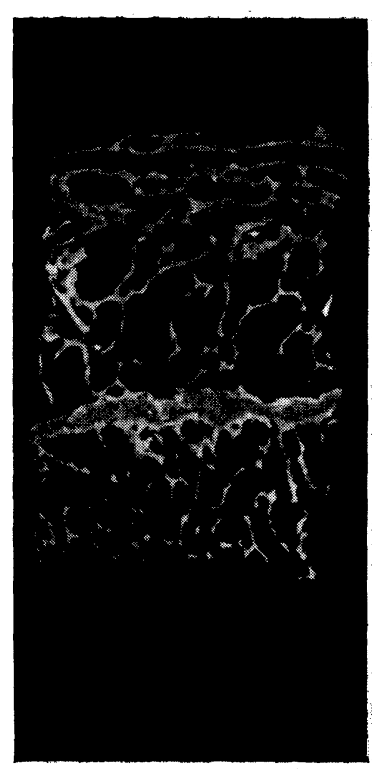

\section{7}

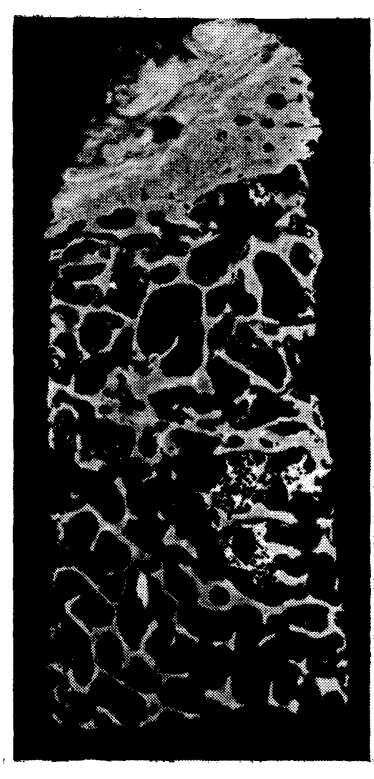

8

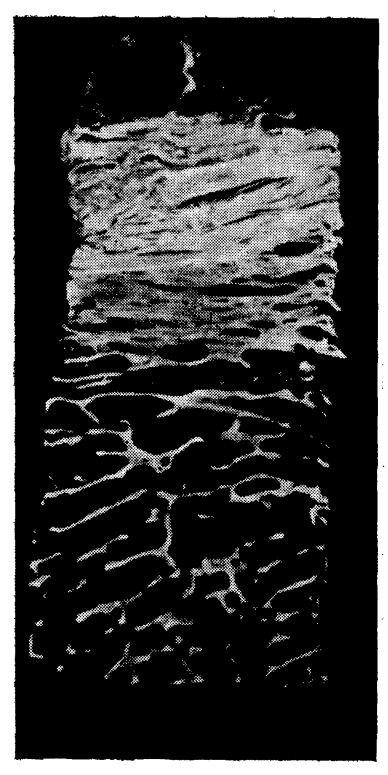

9

Fig. 3. Morphological structure of osseous cylinders from tuber coxae $(\times 5)$.

1, 2 - apophyseal cartilage covers the trabeculae of ala ossis ilii, in the cartilage separated apophyseal ossification centers occur. By their fusion the trabeculae of tuber spongiosa are formed. The surface cartilage in some instances adjoins to growth structures of the cartilage by the cartilage trabeculae (age $1-2$ years).

3 - By ossification of the central parts of apophyseal cartilage it is divided into the superficial and growth cartilage.

4 - After ossification of the superficial cartilage only the growth cartilage is visible. In its structure separated ossification centers can be seen (age 3 years).

$5,6,7$ - In older individuals, the ossification activity in the center of cartilage decreases and the ossification moves to the boundary betren cartilage and bone. The growth cartilage itself become thinner. Ossification proceeds on both ends of the growth cartilage (age 4 to 5 years).

8, 9 - Morphological structure of the bone cylinder in adult cattle. By total ossification of the growth cartilage the bone trabeculae of tuber coxae and ala ossis ilii have been joined (age above 5 years). 


\section{Morfologická klasifikace kostních bioptátů s možností určování skeletového věku skotu}

Na podélných makrořezech kyčelním hrbolem a křidlem kyčelní kosti u 36 zvírat ve věku 1-9 let a na tkáňových řezech 4--7 $\mu \mathrm{m}$ obarvených hematoxylineosinem 240 bioptátů $z$ tuber coxae u zvírat ve věku 8 měsíců až 9 let byl sledován vzájemný vztah apofysární chrupavky a spongiosní kosti. Na základě morfogenetických poznatků makro i mikrostruktury byla zkoumána možnost určení skeletového věku.

V 1. a 2. roce je kyčelní hrbol zcela tvořen apofysární chrupavkou. Samostatné apofysární osifikační body vytvářejí spongiosní kost, která nahrazuje horní část chrupavky. Zbylá chrupavka se tak stává růstovou chrupavkou, na jejíž obou okrajích dochází $\mathrm{k}$ osifikaci. Souvislá enchondrální zóna vytváŕí při distálním okraji trabekuly křídla kyčelní kosti, proximální okraj kyčelní hrbol. K zániku chrupavky dochází ve věku 5-6 let. Výsledky byly srovnávány $s$ nálezy mikrostruktury $\mathrm{v}$ histologických řezech a na základě těchto zjištěni byla provedena klasifikace kostních bioptátů strukturálně odpovídajících jednotlivým věkovým kategoriím.

\section{Морфологическая классификация костных биопрепаратов с возможностыо определения возраста скелета крупного рогатого скота}

На продольных макросрезах большого вертела и крыла таза 36 животньх в возрасте 1-9 лет и на тканевых срезах толщиной 4-7 мкм, окрашенных тематоксилин-эозином 240 биопрепаратов большого вертела животных в возрасте 8 месяцев - 9 лет проводились наблюдения взаимной связи апофизарного хряща и губчатой кости. На основе морфогенетических знаний макрои микроструктуры исследовалась возможность определения возраста скелета.

На 1 и 2 году большой вертел польностью образован апофизарным хрлщом. Самостоятельные апофизарные точки оссификации образуют губчатую кость, заменяющую верхнюю часть, хряща. Остающийся хращ, таким образом, становится ростовым хряшом, по обеим сторонам которого происходит оссификация. Сплошная энхондральная зона образует около нижнего края трабекулы крыла таза, верхний край - большой вертел. Исчезновение хряща происходит в возрасте 5-6 лет. Результаты сравнивались с заключениями в микроструктуре гистологических срезов и на основе упомянутых данных проводилась классификация костных биопрепаратов, соответствующим по структуре отдельным возрастным категориям. 


\section{References}

AKAJEVSKIJ, A. I.: Anatomija domašnich životnych. Kolos, Moskva, 1975, 590.

ALCOCK, N. W.: Calcification of cartilage. Clin. Orthop., 86, 287-311, 1972.

ČERNYY, H.: Hodnocení morfologické struktury v kostních bioptátech skotu vzhledem k poruchám minerálního metabolismu. Thesis, Brno, 1977.

ČERNÝ, H.: Reakce morfologické struktury chrupavky a kostní tkáně při poruchách minerálního metabolismu u mladého skotu. Project report, Brno, 1978.

ELLENBERGER, W. - BAUM, H.: Handbuch der vergleichenden Anatomie der Haustiere. Springer Verlag, Berlin, 1943, 1155.

EVANS, H. E., SACK, W. O.: Prenatal Development of Domestic and Laboratory Mammals: Growth Curves, External Features and Selected References. Anat., Histol., Embryol., 2, 11 - 45, 1973.

KOLDA, J.: Srovnávaci anatomie zvírat domácích se zřetelem $\mathrm{k}$ anatomii člověka. II. Nauka o kostech a chrupavkách. Novina, Brno, 1936.

KRAHMER, R.: Über die Wachtumsveränderungen des Skelettes beim weiblichen Deutschen Schwarzbunten Rind von der Geburt bis zum Wachstumsabschluss (über 5 Jahre), unter besonderer Beachtungs der Gliedmassen. Anat. Anz., 131, 146-156, 1972.

KRUTSAY, M.: UUber die Entkalkung histologischer Untersuchungsobjekte. Zbl. allg. Path., $114,75,1971$.

LINDSAY, F. E. F.: Observations on the loci of ossification in the prenatal and neonatal bovine skeleton. I. The appendicular skeleton. Brit. Vet. J., 125, 101-111, 1969.

LINDSAY, F. E. F.: Observations on the loci of ossification in the prenatal and postnatal bovine skeleton. II. The sternum. Brit. Vet. F., 125, 422-428, 1969.

MAZHUHA, P. M., ZHITNIKOV, A. Y., KHARCHUK, L. N.: Differentiation and reproduction of cells in chondrogenesis. Anat. Anz., 126, 172-181, 1970.

McLEAN, F. C., BLOOM, W.: Calcification in normal growing bone. Anat. Rec., 78, 333 - 352 1940.

SCHENK, R. K.: Zur histologischen Verarbeitung von unentkalkten Knochen. Acta anat. 60, 3-19, 1965.

VASILEV, V.: Wachtumsanatomie des Beckens bei der Kuh. Anat. Anz., 121, 313-326, 1967.

VASILEV, V.: Osteometrie der Altersveränderungen der Becken Knochen und des Beckens als Ganzes bei der Kuh. Anat. Anz,. 123, 315-336, 1968. 